\title{
DESIGNING GIS-BASED SITE SELECTION MODEL FOR URBAN INVESTMENT PLANNING IN SMART CITIES WITH THE CASE OF ELECTRIC VEHICLE CHARGING STATIONS
}

\author{
Suleyman Sisman ${ }^{1}$, Irem Ergul ${ }^{1}$, Arif Cagdas Aydinoglu ${ }^{*}$ \\ ${ }^{1}$ Dept. of Geomatics Engineering, Gebze Technical University, 41400 Gebze, Kocaeli, Turkey - ssisman@gtu.edu.tr; \\ irem.ergul2017@gtu.edu.tr;aydinoglu@gtu.edu.tr
}

KEY WORDS: Decision Support Systems, Geographic Information Systems (GIS), Urban Investment Planning, Site Selection.

\begin{abstract}
:
It is of great importance that different sectoral investments such as energy, technology, education, logistics, health, industry, transportation, construction, tourism, which will be realized in globalizing and crowded cities, are made in the most suitable city areas. In order to obtain the maximum efficiency from the unit city area for any sectoral investment activity and to develop more planned and liveable cities, many decision parameters in investment management should be handled rationally by integrated a geographical perspective. In this study, designing GIS-based site selection models was examined for effective decision-making in the investment planning process for smart cities. In this context, different sectoral investment applications examining implementation requirements were determined for smart cities. Electric vehicle charging stations (EVCS) site selection application was determined as a case study, to design a GIS-based integrated site selection model for investment planning in smart city concept. Data preparation and analysis models were designed for determining the most suitable EVCSs location. EVSC site selection affecting criteria and criteria weights (by MCDA techniques) were researched in the literature. For this purpose, 15 criteria defined by three main criteria groups, namely Environmental/ Geographical, Economic Criteria, and Urbanity Criteria were determined. Designed models were performed analysing EVCSs suitability map in Pendik district of Istanbul. Normalized raster maps related to 15 criteria and EVCSs suitability map were produced with five suitability degrees for the Pendik district. Also, by designing the models, an integrated and planned investment mechanism can be developed for the impressive and efficient use of urban resources in smart city investments.
\end{abstract}

\section{INTRODUCTION}

In parallel by the rapid urbanization patterns emerging nowadays, the importance of deployment of resources has emerged and became a key factor for sustainable development (Zeng et. Al., 2016). In this perspective, effective and continuous urban planning of cities along with the management of economic activities plays significant role for urban policies. Today's city is a combination of complex and connected systems producing high-speed information (Kumar and Dahiya, 2017). A smart city brings the intelligent solutions to the urban management such as the Internet of Things (IoT) and information and communications technology (ICT) (Angelidou, 2017). All these technologies can help to provide better quality of life and feasible management of urban environment. Smart cities can take the advantage of these technological opportunities for profitable investment (Vuppuluri, 2020).

As a main dimension of the smart city concept, smart economy involves the maintainance of the innovation on economic activities that companies and citizens can freely collaborate (Bakici et. al., 2013). Smart city can provide significant opportunities on future investment related to technologies such as smart grids, renewable energy, smart buildings and green energy initiatives like wind enery, solar-power, low carbon energy and electric automobile (Barclays, 2020). The opportunities of big data that is produced within the smart city applications provide the deeper insight for better business decisions to the investors. Applications developed within the smart city implementations can enhance the urban life and economic growth (Kumar and Dahiya, 2017).

Smart cities frequently use the abilities of geographical information systems (GIS) for location-based decision support mechanisms and city governance (Kumar and Dahiya, 2017). In order to develop a holistic and planned investment environment for the impressive and efficient use of resources in smart cities, GIS is an indispensable technology. Urban investment plans can be developed by focusing on the integration of environmental, economic, and social perspectives in GIS-based Multi Criteria Decision Analysis (MCDA) environment. GIS-based site selection in smart cities helps to allocate and monitor funds for sustainable urban economic development, and also supports rational land use and effective management process.

GIS-based MCDA methods are extensively used for various site selection applications in literature for example, nuclear power plant (Aykekum et.al., 2021 Kurt, 2014), thermal power plant (Choudhary and Shankar, 2012) solar power plant (Sun et. al., 2021; Uyan, 2013), logistics terminals (Cakmak et.al., 2021, Liu and Zhang, 2011), education facility (Prasetyo et al., 2018), shipyard (Caner and Aydin, 2021), solid waste landfill site selection (Beskese et al., 2015; Mussa and Suryabhagavan, 2021), electric vehicle charging stations (EVCS) (Guler and Yomralioglu, 2020), hospital (Parvin et.al., 2021; Vahidnia et al., 2009), industrial site (Reisi et al., 2018), airport (Erkan and Elsharida, 2020) car parking (Darani et al., 2018) and fire station (Nyimbili and Erden, 2020).

The main purpose of this paper is to design GIS-based site selection models for effective decision-making in the investment planning process for smart cities. The general frame of this paper is designed as follows: Section 2 describes implementation requirements in investment planning by different site selection applications. In section 3, the GIS-based site selection model by utilizing MCDA techniques was examined for smart cities. In section 4 , by using GIS-based data preparation and analysis models, a case study of site selection for EVCS was conducted in the Pendik, Istanbul. In the last section, namely in section 5 , the results were evaluated. 


\section{IMPLEMENTATION REQUIREMENTS FOR INVESTMENT PLANNING}

Within the context of investment activities in Turkey, appropriate sector-based land inventories should be presented to investors quickly and accurately. For this purpose, 13 priority sectors in Turkey were determined with the Project for Improving the Investment Environment with Geographic Information System (MoEU, 2017). In the process of determining these sectors, the 10th Development Plan, Regional Development Plans, 2023 Investment Targets, OECD Investment Plans, Action Plans of Chambers of Commerce and Industry, Public-Private Partnership Program, Ministries (Ministry of Health, Ministry of National Education, Ministry of Environment of Urbanisation, Ministry of Energy and Natural Resources, Ministry of Transport and Infrastructure) Strategy Plans, Rural Development Action Plans, priority investment supports of the Ministry of Trade, plans of the Ministry of Foreign Affairs, priorities of the Ministry of Treasury and Finance, priorities of the Ministry of Trade, priorities of Presidency of The Republic of Turkey Investment Office, Priorities of Investor Ministries, 2023 - 2071 Targets, and Investment Advisory Council final report documents were taken into account.

These sector applications are as follows, respectively: 1Thermal power plant, 2- Nuclear power plant, 3- Solar power plant, 4- Logistics terminals, 5- Technology development zone, 6- School areas, 7 - Automotive industry, 8- Dairy/ fattening facility, 9- Hospital, 10- Organized industrial zone, 11Ecotourism, 12- Housing estate and 13- Solid waste landfill. In addition to these sectors, other priority applications were added for investment planning in smart cities. Some of these are as follows; 14- car parking (Iqbal, 2020), 15- urban agricultural areas (Ustaoglu et al., 2021), 16- urban construction land (Ustaoglu and Aydinoglu, 2020b), 17- electric vehicle charging stations (EVCS) (Erbaş et al., 2018), and 18- providing land value information (Bovkir and Aydinoglu, 2018).

In this context, the relevant criteria and data requirements for a total of 18 site selection applications were analyzed. To perform site selection analysis in GIS-based MCDA techniques, defined influential criteria (by main and sub-criteria) and required geographical data sets were determined according to the literature review and application background. As a part of National GIS Infrastructure (TUCBS), it is supposed that an integrated site selection mechanism can be provided when the data sets are available for these applications.

\section{DESIGN OF GIS-BASED SITE SELECTION MODEL}

When site selection analysis are performed for different application needs, various criteria are evaluated simultaneously in the GIS environment. The purpose of GIS-based site selection analysis is to determine the potential (suitable) sites for various facility activities. These analysis are determined not only the site suitability but also the degree of suitability level (Ustaoglu and Aydınoglu, 2020a).

Any site selection analysis process with GIS-based MCDA techniques can generally be defined in five interconnected steps. In the first step, criteria are determined for the relevant site selection problem. The criteria are defined according to the literature review and expert opinion.

In the second step, geographical and non-geographical data for the defined criteria are obtained from official and private-sector databases and open data portals. The obtained data are analyzed using various geographic analysis techniques (e.g. proximity, interpolation, surface analysis, etc.) in the GIS environment. The attribute values of all data layers used in the site selection analysis are normalized within the same value range so that the final suitable analysis index maps can be produced correctly. Analysis results are stored in geo-databases in raster data format and made ready for use for site selection analysis.

In the third step, criteria weights are determined that indicate the importance levels of the defined criteria relative to each other. Different MCDA methods are typically used to calculate criterion weights in GIS-based site selection studies.

MCDA is a set of systematical analysis procedures for effectively solving sophisticated decision problems like site selection. It aims to relate by splitting the complex decision problem into smaller, more simple, and more comprehensible partitions so that more significant results can be concluded from these partitions. (Malczewski, 1999). With the use of these methods, decision-makers develop alternative solutions to find the best solution by taking into account many criteria. The main purpose of using The common purpose of MCDA methods is to kept down the decision-making mechanism under control in cases where the number of alternatives and criteria is high and to achieve the final decision result as quite easily and quickly as possible. The together use of MCDA methods and GIS and can be evaluated as a process that converts and associates geographical data and decision-makers preferences to achieve final knowledge in the decision-making process (Malczewski, 2007; Malczewski and Rinner, 2015). On the other hand, nowadays, there are many MCDA methods. Commonly used among these methods are Analytic Hierarchy Process (AHP), Analytic Network Process (ANP), Best Worst Method (BWM), Technique for Order Preference by Similarity to Ideal Solution (TOPSIS), Weighted Linear Combination (WLC) and Preference Ranking Organization Method for Enrichment of Evaluations (PROMETHEE). The AHP method which is proposed by Saaty (1980) has been the most favored method for criterion weighting in site selection studies due to its easy use. The important issue in the use of the AHP method is to define the main criteria groups consistent with a purpose and the subcriteria related to these groups in a hierarchical structure. The AHP method concentrates on a pair-wise comparison process and some mathematical calculations to enhance scales of preferences among alternatives decisions (Ustaoglu and Aydinoglu, 2020b). AHP method handles different groups of decision actors/experts and also can be utilized in stakeholder analysis (Ramanathan, 2001; Taibi and Atmani 2017). Criterion weights are calculated with the process given in Figure 1 for site selection analysis using AHP method.

In the fourth step, a GIS-based analysis implementation model is designed for the relevant site selection study. GIS-based graphical models can be used to reduce repetitions, automatize the geo-analysis process for any site selection application. Also, they provide performing the site selection process quickly and effectively. Combinations of different geographical analysis techniques can be used in the designed models by adapting them according to the site selection application requirements. Designing GIS-based site selection analysis model can be easily performed commercial (e.g. ArcGIS) and open source (Quantum GIS) GIS software. 


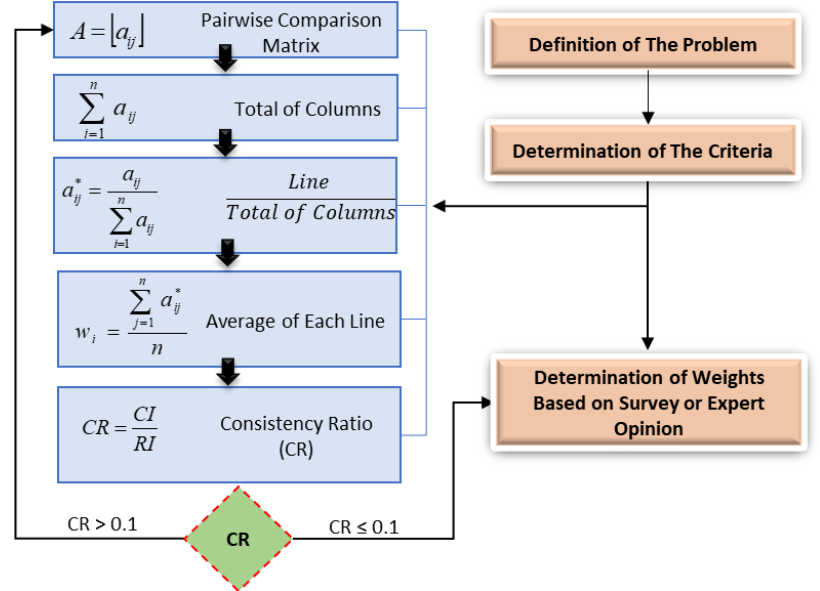

Figure 1. The AHP method implementation process (Sisman and Aydinoglu, 2020).

In the fifth step, the designed analysis models are run and a site selection suitability map is produced. Using the suitability maps produced, alternative areas are evaluated with a GIS perspective. The implementation methodology for GIS-based site selection studies, the general process of which is explained by five steps, is summarized in Figure 2.

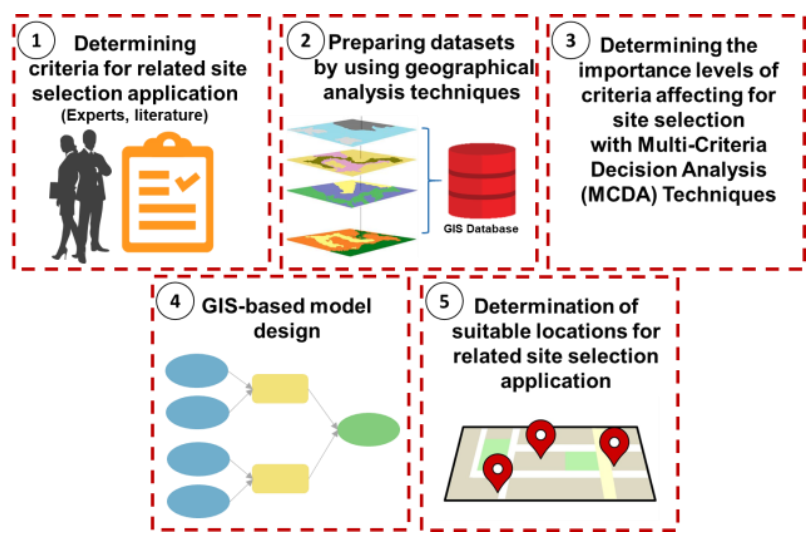

Figure 2. GIS-based site selection methodology general process.

\section{CASE STUDY}

A GIS-based integrated site selection was designed on the scope of investment planning in smart city concept. Among 18 sector applications explained before, site selection application for the EVCSs was carried out as a case study.

\subsection{The study area}

The Pendik district of the Istanbul city was determined as the study area for the application of the GIS-based model designing. Pendik district, located on the Anatolian side of Istanbul, is a district with a coast to the Sea of Marmara. It is surrounded by Gebze in the east, Tuzla in the southeast, Şile and Çekmeköy in the north, Kartal, Sancaktepe and Sultanbeyli in the west, and the Marmara Sea in the south. It has a surface area of approximately $278 \mathrm{~km}^{2}$ and has a $9 \mathrm{~km}$ coastline. The district has 36 neighborhoods and has a population of 726,491 in terms of population, according to Turkish Statistical Institute (TUIK) 2020 data (TUIK, 2020). It is also the fourth district of Istanbul and the largest district on the Anatolian side (Figure 3).

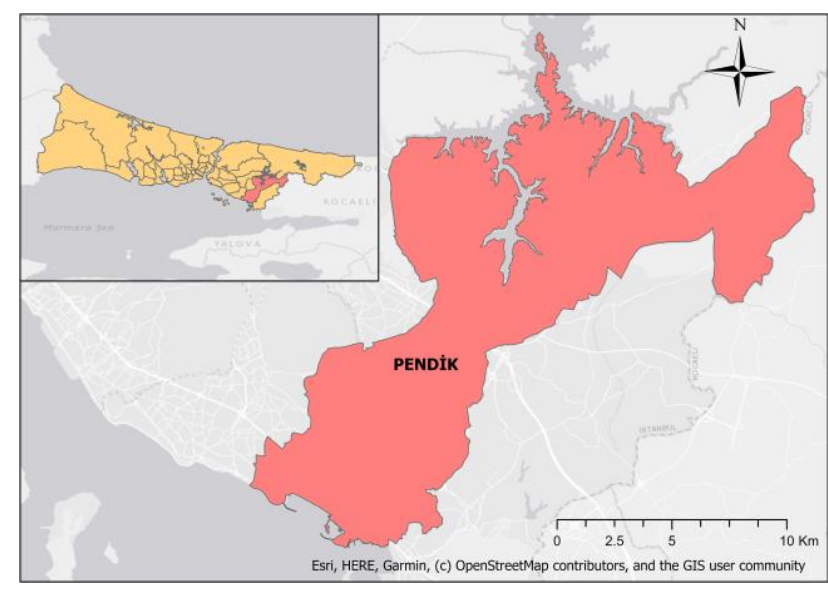

Figure 3. The study area.

\subsection{Determining EVCS site selection criteria and weights}

EVSC site selection affecting criteria and criteria weights were researched in the literature. For this purpose, 15 criteria defined by three main criteria groups, namely Environmental/ Geographical, Economic Criteria, and Urbanity Criteria, were determined. The criterion weights coefficients, which specify the importance levels of the criteria with respect to each other, were determined according to Erbaş et al 2018. Main criteria, sub-criteria, and definition were explained with criteria weights in Table 1.

When Table 1 was examined, the highest main criteria group weight belonged to the economic criteria. On the other hand, in the Environmental/ Geographical criteria group, distance to vegetation; in the Economic Criteria group, EV ownership in the service area; in the Urbanity Criteria group Service area population had the highest weight.

\subsection{GIS-based model design}

Two models were designed using the model builder tool in ArcGIS Pro 2.7 software for the GIS-based assessment of potential areas to build EVCSs. The first of the models was data preparation that is applicable for all site selection models. In this model, raster layers were produced by using euclidean distance, slope, inverse distance weighted, and kernel density geographical analysis techniques for the criteria.

In the second model, the analysis techniques were used for the 15 criteria affecting the EVCS site selection. A two-stage process was performed. In the first stage, all criteria were normalized in the range of $0-1$ using the raster calculator tool. Then, produced maps were reclassified. In the second stage, the criteria weights defined in Table 1 were used to take into consideration the importance levels of the EVCS criteria in the combining process (by weighted sum analysis) of the layers produced by the data preparation model. The graphical display of the designed GIS-based EVCS analysis model was given in Figure 5. However, due to lack of data for the two criteria (1Possibility of expansion, 2- EV ownership in the service area), raster maps were produced with an entire value of 1 . This situation does not affect the running of the designed model. 


\begin{tabular}{|c|c|c|}
\hline $\begin{array}{c}\text { Main } \\
\text { criteria }\end{array}$ & Sub-criteria and Definition & Weights \\
\hline \multirow{6}{*}{$\begin{array}{c}\text { Environ } \\
\text { mental/ } \\
\text { Geograp } \\
\text { hical } \\
\text { Criteria } \\
(0.187)\end{array}$} & $\begin{array}{l}\text { Distance to vegetation: Because the } \\
\text { construction of EVCSs may have } \\
\text { negative impacts on natural vegetation } \\
\text { (green spaces), they should be } \\
\text { constructed away from it. }\end{array}$ & 0.109 \\
\hline & $\begin{array}{l}\text { Distance to water resources: Because } \\
\text { the construction of EVCSs may have } \\
\text { negative impacts on city water sources } \\
\text { (green spaces), they should be built } \\
\text { constructed away from water sources. }\end{array}$ & 0.022 \\
\hline & $\begin{array}{l}\text { Distance to landslide risk: The EVCSs } \\
\text { should not be constructed in landslide } \\
\text { hazard areas. }\end{array}$ & 0.053 \\
\hline & $\begin{array}{l}\text { Slope of land: The EVCSs should be } \\
\text { constructed on an area that is flat (e.g.no } \\
\text { more than } 7 \% \text { ) for low-construction } \\
\text { cost. }\end{array}$ & 0.028 \\
\hline & Possibility of expansion & 0.011 \\
\hline & $\begin{array}{l}\text { Earthquake risk: The EVCSs should } \\
\text { be constructed away from earthquake } \\
\text { areas (fault lines). }\end{array}$ & 0.039 \\
\hline \multirow{3}{*}{$\begin{array}{c}\text { Economi } \\
\text { c Criteria } \\
(0.462)\end{array}$} & $\begin{array}{l}\text { Land cost: The land cost of the EVCSs } \\
\text { should not be high to reduce the total } \\
\text { costs of construction. }\end{array}$ & 0.094 \\
\hline & $\begin{array}{l}\text { Electric vehicle ownership in the } \\
\text { service area: In order to provide many } \\
\text { owners to access charging services, the } \\
\text { electric vehicle ownership ratio in the } \\
\text { service area should be high. }\end{array}$ & 0.197 \\
\hline & $\begin{array}{l}\text { Distance to power cut: The EVCSs } \\
\text { should be constructed in areas away } \\
\text { from continuously happening power } \\
\text { cuts. }\end{array}$ & 0.128 \\
\hline \multirow{6}{*}{$\begin{array}{l}\text { Urbanity } \\
\text { Criteria } \\
(0.351)\end{array}$} & $\begin{array}{l}\text { Service area population: It means the } \\
\text { number of electric vehicles that can } \\
\text { reach the charging service provided by } \\
\text { EVCSs. }\end{array}$ & 0.109 \\
\hline & $\begin{array}{l}\text { Proximity to junctions: The EVCSs } \\
\text { should be close junctions to maximize } \\
\text { the number of cars that reach the } \\
\text { service. }\end{array}$ & 0.059 \\
\hline & $\begin{array}{l}\text { Proximity to main roads: The EVCSs } \\
\text { should be close main roadways to } \\
\text { maintain the vehicles working. }\end{array}$ & 0.102 \\
\hline & $\begin{array}{l}\text { Proximity to substation: The potential } \\
\text { location of the EVCSs should be close } \\
\text { to the substations. }\end{array}$ & 0.020 \\
\hline & $\begin{array}{l}\text { Proximity to petrol station: Because } \\
\text { hybrid cars use petroleum products, the } \\
\text { potential location of the EVCSs should } \\
\text { be close to petrol stations. }\end{array}$ & 0.009 \\
\hline & $\begin{array}{l}\text { Distance to other EVCSs: New EVCSs } \\
\text { to be constructed should be constructed } \\
\text { away from other existing EVCSs. }\end{array}$ & 0.020 \\
\hline
\end{tabular}

Table 1. Weights of criteria computed fuzzy AHP method (Adapted from Erbaş et al., 2018).

Results can be reproduced quickly if data is available for the study area. In addition, raster maps were produced for 15 EVCS criteria (Figure 4). The EVCS suitability map produced by the consecutive use of data preparation and EVCS analysis model for Pendik district of Istanbul was given in Figure 6.

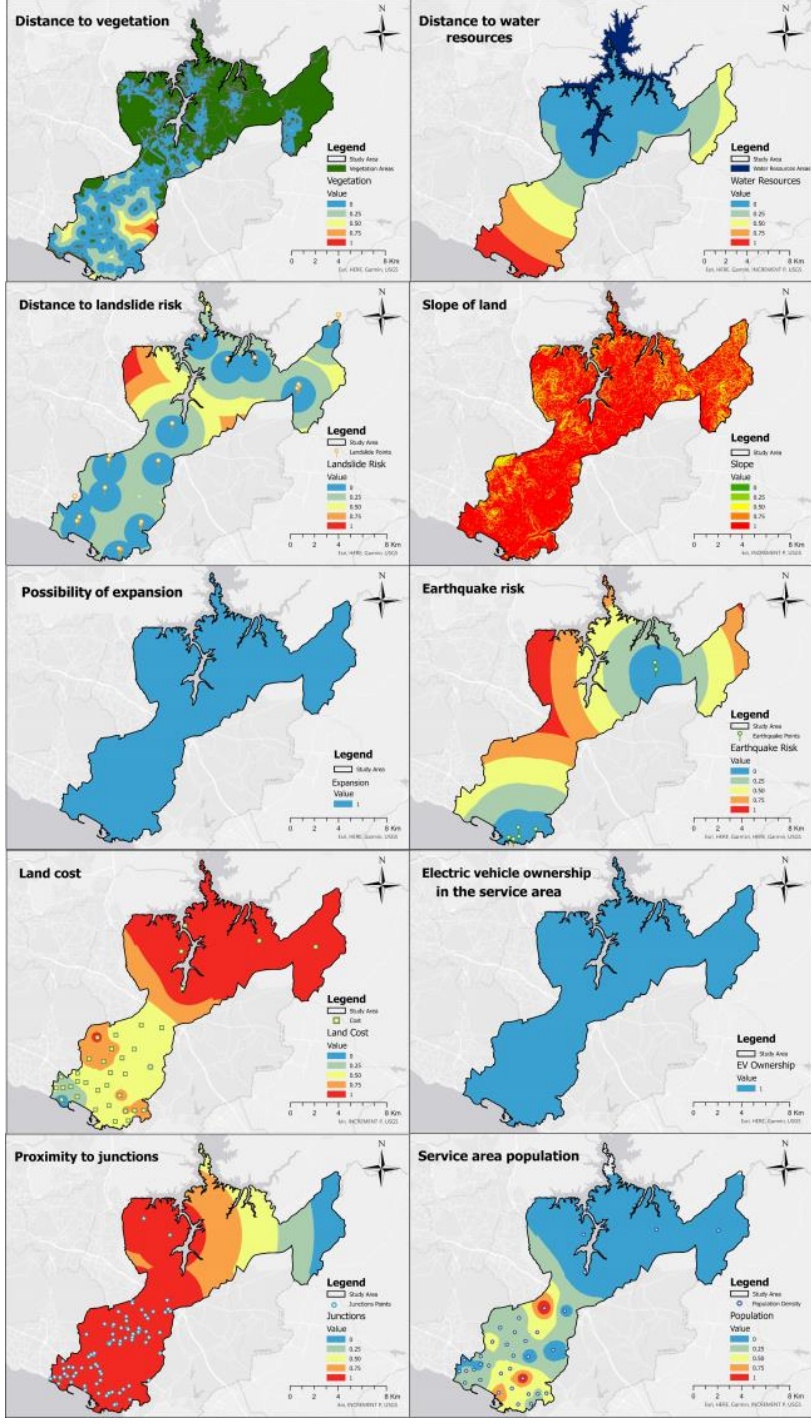

Figure 4. Standardized maps produced by designed models for the EVCSs site selection in Pendik, Istanbul 


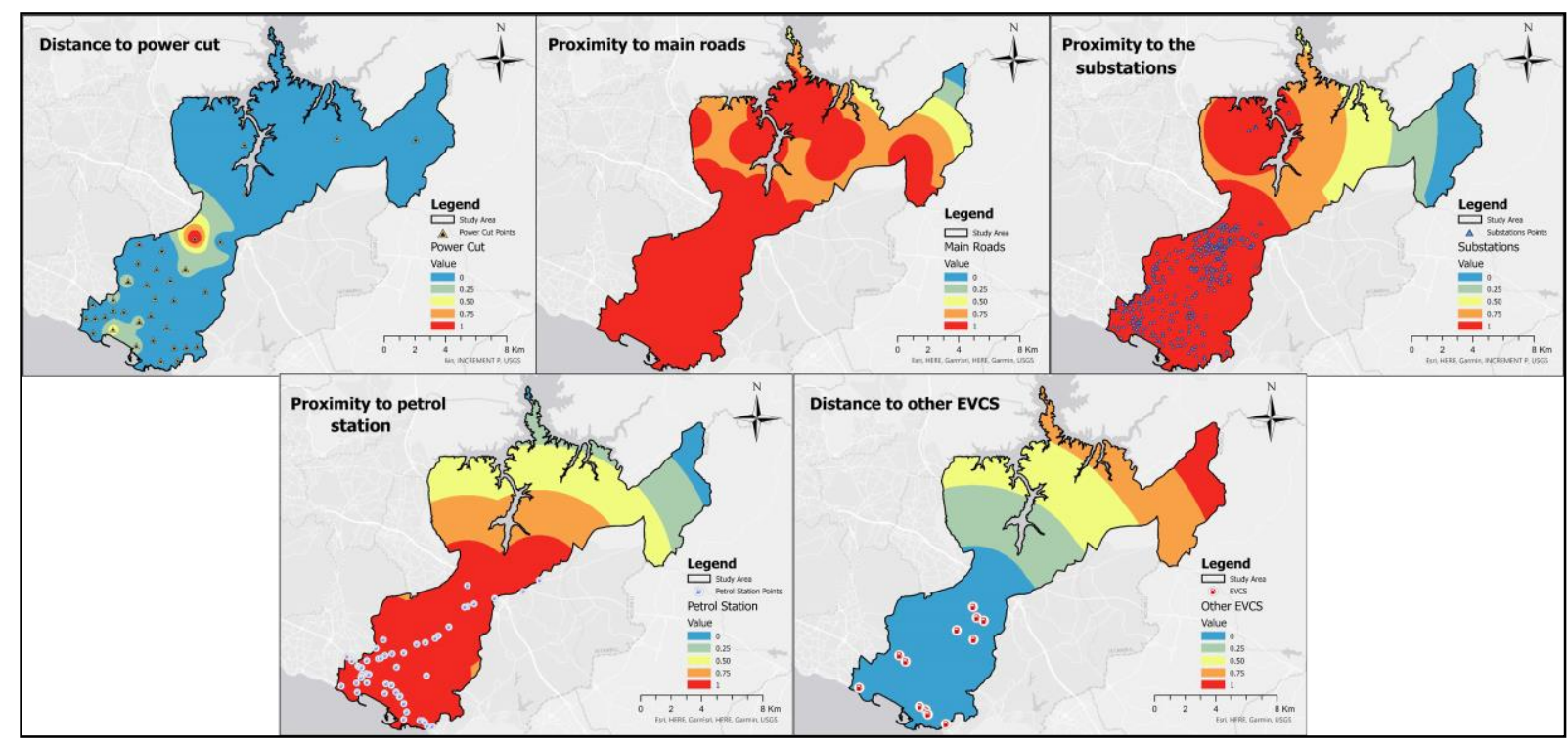

Figure 4. (Contiune).

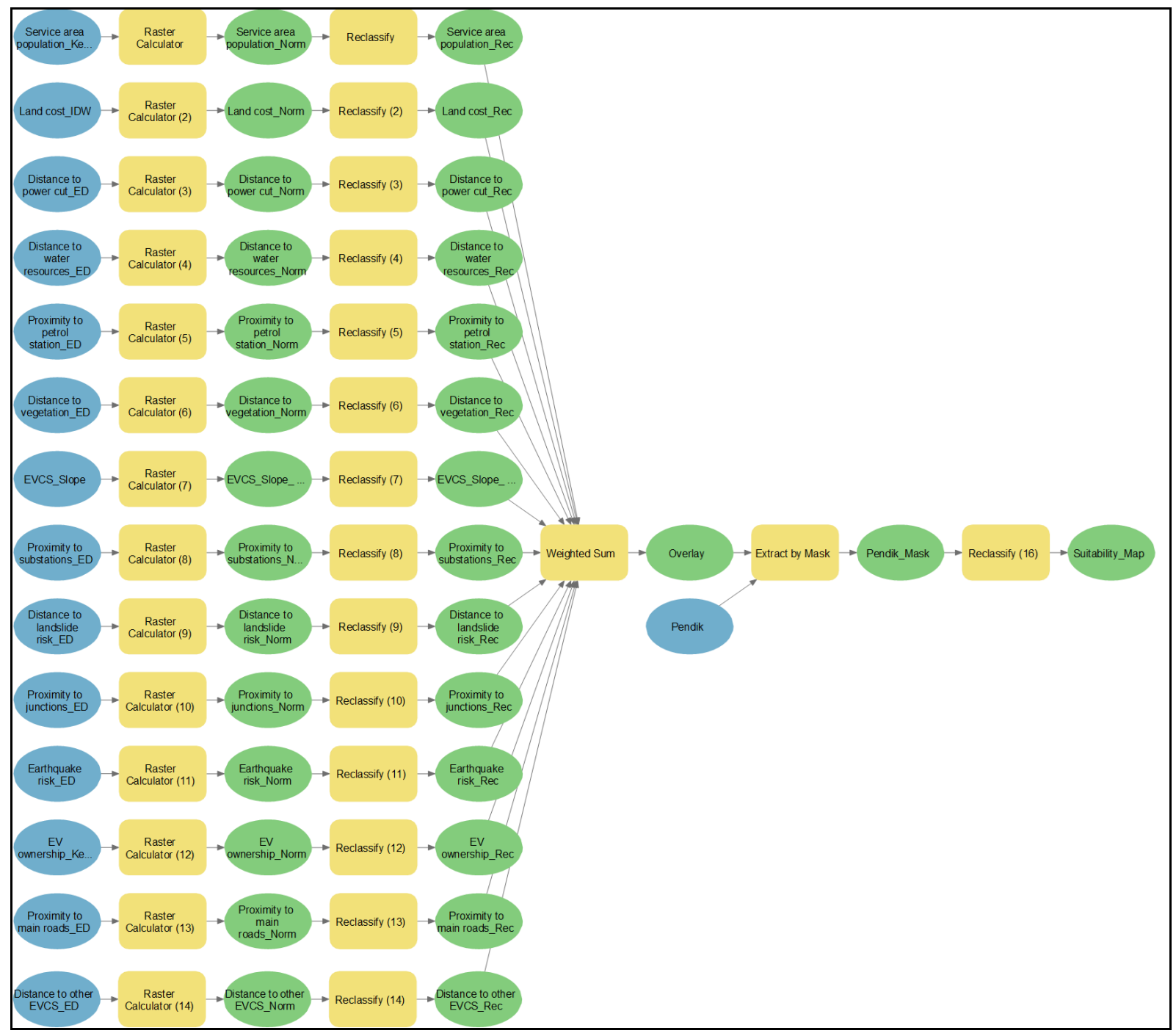

Figure 5. GIS-based EVCSs analysis model. 


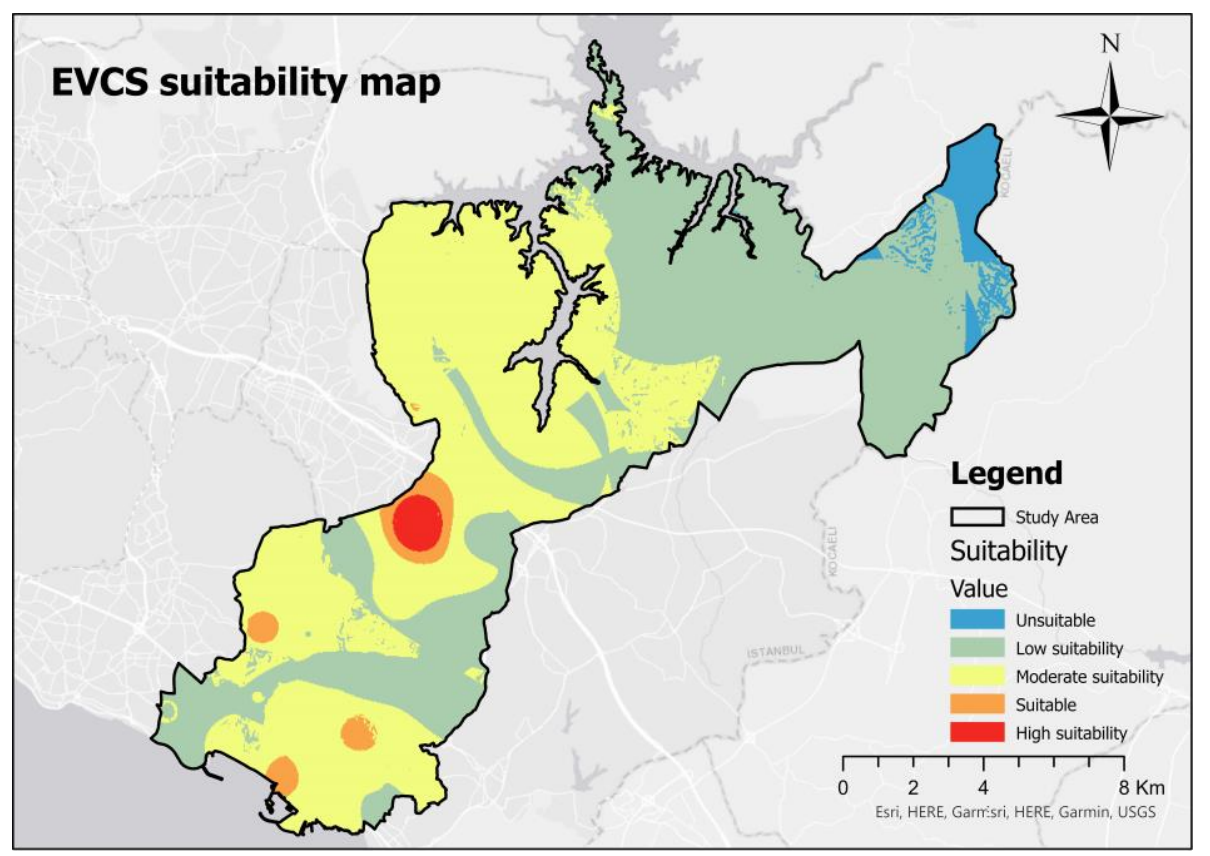

Figure 6. EVCSs suitability map (produced by designed GIS-based models) for Pendik, Istanbul.

\section{DISCUSSION AND CONCLUSION}

It is of great importance that different sectoral investments such as energy, technology, education, logistics, health, industry, transportation, construction, tourism, which will be realized in globalizing and crowded cities, are made in the most suitable city areas. In order to obtain the maximum efficiency from the city area for any sectoral investment activity and to develop more planned and liveable cities, many decision parameters in investment management should be considered rationally by an integrated geographical perspective. Today, this assessment can be performed quickly thanks to developing GIS-based technologies and different MCDA techniques.

In smart cities, a large amount of data is used in the detection and solution of geographical problems such as site selection and resource allocation for investment planning, and many and different criteria are used in which these data are included in the process. Evaluation of data related to a large number of criteria and criteria leads to a take a long time of the decision-making process determining suitable areas in any investment activity. In order to take a short time the decision-making process and make it more objective, MCDA techniques, in which many criteria are evaluated simultaneously from environmental, economic, social, and technical respects, can be used effectively. By these techniques (e.g AHP, FAHP, BWM) the importance level of decision criteria can be determined relative to each other. On the other hand, GIS-based models can be designed to automate the decision-making process in site selection for any investment planning. By the designed models, various geographical analyzes can be performed automatically on different data sets. In this way, detailed geographical operations that should always be done with the designed models can be carried out in a very short time.

In summary, quick/real-time and effective decision-support strategies can be developed with GIS-based site selection models, in which GIS and MCDA techniques are designed in a hybrid structure. By the designed models, an integrated and planned investment mechanism can be developed for the impressive and efficient use of urban resources in smart city investments. In addition, the designed models can be adapted for different sectoral investment applications, which include quite different decision scenarios in the concept of smart cities, to offer investors alternative geographic decision support strategies. Electrical vehicle and vehicle-to-vehicle network technologies are developing nowadays as a part of automotive industry. Site selection and optimization problems has been an important research issue for these new generation automobiles.

\section{REFERENCES}

Angelidou, M. 2017. Smart city planning and development shortcomings. TeMA - Journal of Land Use, Mobility and Environment, 10(1), 77-94. https://doi.org/10.6092/19709870/4032

Agyekum, E. B., Amjad, F., Aslam, F., Ali, A. 2021. Application of Weighted Linear Combination approach in a Geographical Information System environment for nuclear power plant site selection: the case of Ghana. Annals of Nuclear Energy, 162, 108491.

Bakıc1, T., Almirall, E. Wareham, J. A Smart City Initiative: the Case of Barcelona. J Knowl Econ 4, 135-148 (2013). https://doi.org/10.1007/s13132-012-0084-9

Barclays, 2020. Rethinking Smart Cities: Prioritising infrastructure, Insight Report. Accessed at: https://www.investmentbank.barclays.com/ourinsights/Rethinki ng-smart-cities-prioritising-infrastructure.html (12.07.2021)

Beskese, A., Demir, H. H., Ozcan, H. K., Okten, H. E. 2015. Landfill site selection using fuzzy AHP and fuzzy TOPSIS: a case study for Istanbul. Environmental Earth Sciences, 73(7), 3513-3521. https://doi.org/10.1007/s12665-014-3635-5 
Bovkir, R., Aydinoglu, A. C. 2018. Providing land value information from geographic data infrastructure by using fuzzy logic analysis approach. Land use policy, 78, 46-60.

Caner, H. I., Aydin, C. C. 2021. Shipyard site selection by raster calculation method and AHP in GIS environment, İskenderun, Turkey. Marine Policy, 127, 104439.

Cakmak, E., Onden, I., Acar, A. Z., Eldemir, F. 2021. Analyzing the location of city logistics centers in Istanbul by integrating Geographic Information Systems with Binary Particle Swarm Optimization algorithm. Case Studies on Transport Policy, 9(1), 59-67.

Chen, K., Blong, R., Jacobson, C. 2001. MCE-RISK: Integrating multicriteria evaluation and GIS for risk decisionmaking in natural hazards. Environmental Modelling and Software, 16(4), 387-397. https://doi.org/10.1016/S13648152(01)00006-8

Choudhary, D., Shankar, R. 2012. An STEEP-fuzzy AHPTOPSIS framework for evaluation and selection of thermal power plant location: A case study from India. Energy, 42(1), 510-521. https://doi.org/10.1016/j.energy.2012.03.010

Darani, S. K., Eslami, A. A., Jabbari, M., Asefi, H. 2018. Parking lot site selection using a fuzzy AHP-TOPSIS framework in Tuyserkan, Iran. Journal of Urban Planning and Development, 144(3). https://doi.org/10.1061/(ASCE)UP.19435444.0000456

Erbaş, M., Kabak, M., Özceylan, E., \& Çetinkaya, C. 2018. Optimal siting of electric vehicle charging stations: A GISbased fuzzy Multi-Criteria Decision Analysis. Energy, 163, 1017-1031. https://doi.org/10.1016/j.energy.2018.08.140

Erkan, T. E., Elsharida, W. M. 2020. Combining AHP and ROC with GIS for Airport Site Selection: A Case Study in Libya. ISPRS International Journal of Geo-Information, 9(5), 312.

Guler, D., Yomralioglu, T. 2020. Suitable location selection for the electric vehicle fast charging station with AHP and fuzzy AHP methods using GIS. Annals of GIS, 26(2), 169-189. https://doi.org/10.1080/19475683.2020.1737226

Iqbal, A. S. 2020. A GIS-based parking demand analysis and site selection for parking area: Pendik-Istanbul case, Master Thesis, Gebze Technical University.

Kumar, T. V., Dahiya, B. 2017. Smart economy in smart cities. In Smart economy in smart cities (pp. 3-76). Springer, Singapore.

Kurt, Ü. 2014. The fuzzy TOPSIS and generalized Choquet fuzzy integral algorithm for nuclear power plant site selection A case study from Turkey. Journal of Nuclear Science and Technology, 51(10), 1241-1255. https://doi.org/10.1080/00223131.2014.918524

Liu, H., Zhang, X. 2011. Study on location selection of multiobjective emergency logistics center based on AHP. Procedia Engineering, 15 , 2128-2132. https://doi.org/10.1016/j.proeng.2011.08.398

Malczewski, J. W. 1999. GIS and Multi Criteria Decision Analysis. In Computers \& Geosciences (1st ed., Vol. 26, p. 392)
Malczewski, J. 2007. GIS-based multicriteria decision analysis: A survey of the literature. International Journal of Geographical Information Science, 20(7), 703-726. https://doi.org/10.1080/13658810600661508

Malczewski, J., Rinner, C. 2015. Multicriteria Decision Analysis in Geographic Information Science. In Analysis methods (Issue Massam 1993). Springer Berlin Heidelberg. https://doi.org/10.1007/978-3-540-74757-4

MoEU, 2017. Improving the Investment Environment with Geographic Information System. Project Report, Ministry of Environment and Urbanisation.

Mussa, A., Suryabhagavan, K. V. 2021. Solid waste dumping site selection using GIS-based multi-criteria spatial modeling: a case study in Logia town, Afar region, Ethiopia. Geology, Ecology, and Landscapes, 5(3), 186-198.

Nyimbili, P. H., Erden, T. 2020. GIS-based fuzzy multi-criteria approach for optimal site selection of fire stations in Istanbul, Turkey. Socio-Economic Planning Sciences, 71(July 2019), 100860. https://doi.org/10.1016/j.seps.2020.100860

Parvin, F., Ali, S. A., Hashmi, S., Khatoon, A. 2021. Accessibility and site suitability for healthcare services using GIS-based hybrid decision-making approach: a study in Murshidabad, India. Spatial Information Research, 29(1), 1-18.

Prasetyo, D. H., Mohamad, J., Fauzi, R. 2018. A GIS-based multi-criteria decision analysis approach for public school site selection in Surabaya, Indonesia. Geomatica, 72(3), 69-84.

Ramanathan, R. 2001. A note on the use of the analytic hierarchy process for environmental impact assessment. Journal of environmental management, 63(1), 27-35.

Reisi, M., Afzali, A., Aye, L. 2018. Applications of analytical hierarchy process (AHP) and analytical network process (ANP) for industrial site selections in Isfahan, Iran. Environmental Earth Sciences, 77(14), 1-13. https://doi.org/10.1007/s12665018-7702-1

Saaty, T. L. 1980. The Analytic Hierarchy Process Mcgraw Hill, New York. Agricultural Economics Review, 70.

Sisman, S., Aydinoglu, A. C. 2020. Using GIS-Based MultiCriteria Decision Analysis Techniques In The Smart Cities. The International Archives of Photogrammetry, Remote Sensing and Spatial Information Sciences. https://doi.org/10.5194/isprsarchives-XLIV-4-W3-2020-383-2020

Sun, L., Jiang, Y., Guo, Q., Ji, L., Xie, Y., Qiao, Q., . Xiao, K. 2021). A GIS-based multi-criteria decision making method for the potential assessment and suitable sites selection of PV and CSP plants. Resources, Conservation and Recycling, 168, 105306 .

Taibi, A., Atmani, B. 2017. Combining Fuzzy AHP with GIS and Decision Rules for Industrial Site Selection. International Journal of Interactive Multimedia \& Artificial Intelligence, 4(6).

TUIK, 2020. Turkish Statistical Institute, Population and Demographic Statistics. https://www.tuik.gov.tr/. 2020 (10 June 2020). 
Ustaoglu, E., Aydınoglu, A. C. 2020a. Site suitability analysis for green space development of Pendik district (Turkey). Urban Forestry and Urban Greening, 47, 126542. https://doi.org/10.1016/j.ufug.2019.126542

Ustaoglu, E., Aydınoglu, A. C. 2020b. Suitability evaluation of urban construction land in Pendik district of Istanbul, Turkey. Land Use Policy, 99, 104783. https://doi.org/10.1016/j.landusepol.2020.104783

Ustaoglu, E., Sisman, S., Aydınoglu, A. C. 2021. Determining agricultural suitable land in peri-urban geography using GIS and Multi Criteria Decision Analysis (MCDA) techniques. Ecological Modelling, 455, 109610.

Uyan, M. 2013. GIS-based solar farms site selection using analytic hierarchy process (AHP) in Karapinar region Konya/Turkey. Renewable and Sustainable Energy Reviews, 28, 11-17. https://doi.org/10.1016/j.rser.2013.07.042

Vahidnia, M. H., Alesheikh, A. A., Alimohammadi, A. 2009. Hospital site selection using fuzzy AHP and its derivatives. Journal of Environmental Management, 90(10), 3048-3056. https://doi.org/10.1016/j.jenvman.2009.04.010

Vuppuluri, P., 2020. Investing In Innovation: The Rise Of The Smart City. Forbes Magazine. Accessed at: https://www.forbes.com/sites/forbesfinancecouncil/2020/12/03/i nvesting-in-innovation-the-rise-of-the-smart city/?sh=7d5f82875ba6 (12.07.2021).

Zadeh, L. A. 1968. Fuzzy algorithms. Information and Control, 12(2), 94-102. https://doi.org/10.1016/S0019-9958(68)90211-8

Zeng, C., Deng, X., Dong, J., Hu, P. 2016. Urbanization and sustainability: comparison of the processes in "BIC" countries. Sustainability, 8(4), 400. https://doi.org/10.3390/su8040400 